\title{
Short Technical Report Production of Bulk Amounts of Universal RNA for DNA Microarrays
}

L.G. Puskás, Á. Zvara, L. Hackler Jr., T. Micsik, and P. van Hummelen ${ }^{1}$

Hungarian Academy of Sciences, Szeged, Hungary, and ${ }^{1}$ Flanders Interuniversity Institute for Biotechnology (VIB), Leuven, Belgium

\footnotetext{
ABSTRACT

In DNA microarray technology, repeatability and reliability are very important to compare multiple RNA samples from different experiments. The application of common or universal RNA as a standard control equalizes the differences in hybridization parameters and array variations. For this purpose, high-quality reference RNA is necessary in bulk amounts. A novel approach was developed to get milligrams of sense or antisense RNA, starting from micrograms of pooled total RNA from different cell lines, tissues, or organisms. This method is inexpensive and allows further labeling procedures using poly(dT) or random oligomers as primers. In addition, amplified, sense reference RNA is suitable for standard labeling protocols, while the antisense reference RNA can be used with antisense RNA from the linear sample amplification method. Here we produced universal RNA for human, rat, and alfalfa and demonstrated the quality using specific cDNA microarrays.
}

\section{INTRODUCTION}

In DNA microarray technology for each hybridization, a mixture of two fluorescent labeled probes is usually applied, where one labeled probe is obtained from a control (untreated, unaffected) and the other is from a treated or affected sample (5). This direct comparative hybridization method allows a quantitative comparison of the relative abundance of individual sequences, although experimental variation introduced by the uneven incorporation of labels, differences in hybridization, washing, and reading often occurs $(3,5)$. It can cause discrepancies in relative and accurate comparisons of separate experimental results, especially when they are performed by different research laboratories or at different times. Many efforts have been made to minimize these variations by purchasing accurate hybridization chambers sold by different companies, although they cannot solve the problems caused by the incorporation and uneven distribution of samples on microarrays. While kits are available to optimize the labeling step, there is no consensus, even in protocols applied by different groups. The most reliable approach to overcome these problems is the indirect comparison of signal intensities. In these kinds of experiments, each mRNA sample is compared to a reference mRNA pool composed of an equal mixture of all experimental RNA targets. The importance of this approach was first suggested by Eisen and Brown (2) and used in the comparison of different cancer cell lines (7) and different non-Hodgkin's lymphomas (1). The application of a common reference RNA pool in each cDNA microarray experiment allows the relative gene expression in multiple samples to be analyzed. It is very difficult to obtain reliable reference RNA not only because of its need for complexity but also because of the large quantity. Today, universal reference RNA is commercially available but is extremely expensive for routine use. To obtain reference RNA from pooled, high-quality RNA, RNA isolation should be performed from cell lines representing different tissues or from different tissue samples. However, this is costly and time consuming if one wants to obtain milligrams of highly purified RNA.

We developed a novel amplification technique based on PCR amplification and a modified version of an in vitro amplification (http://www.microarrays.org/pdfs/ModifiedEberwine.pdf) to obtain high-quality reference RNA in bulk amounts, starting from micrograms of mixed total RNA. Amplification of mRNAs without distortion of their initial ratios was previously presented (6). Both antisense and sense amplified RNA can be synthesized with this method and can be used as standards in diverse microarray studies. 


\section{MATERIALS AND METHODS}

\section{Construction of cDNA Microarrays}

PCR-amplified cDNA fragments were spotted in duplicate on aminoalkyl-silane-treated microscope slides (Silane-Prep $^{\text {TM }}$ Slides; Sigma, St. Louis, MO, USA) using a MicroGrid Total Array System printer (BioRobotics, Cambridge, UK). The cDNA clones were obtained from mixed libraries, cloned in pBluescript ${ }^{\circledR} \mathrm{SK} \mathrm{II}^{-}$ (New England Biolabs, Hertfordshire, UK) or pGEM $^{\circledR}$ (Promega, Madison, WI, USA) plasmids with standard cloning techniques. The cDNA inserts were amplified with vector-specific primers, purified with the Montage ${ }^{\mathrm{TM}}$ $\mathrm{PCR}_{96}$ Cleanup Kit (Millipore, Bedford, MA, USA), resuspended in 50\% DMSO/water, and loaded into a 384well format microplate. Post-processing of DNA arrays was performed as described previously (6).

\section{RNA Extraction and RNA Pools}

For the production of rat reference RNA, commercially available total RNA were pooled. RNA $(5 \mu \mathrm{g})$ from each of the following tissues were mixed: liver, brain, thymus, heart, lung, spleen, testicle, ovary, and kidney. Rat embryo total RNA $(35 \mu \mathrm{g})$ was added to this mixture. All of the RNA was purchased from Ambion (Austin, TX, USA). For human reference RNA, 60 $\mu \mathrm{g}$ Universal Human Reference RNA (pooled from 10 different cell lines representing different tissues; Stratagene, La Jolla, CA, USA) was mixed with 5 $\mu \mathrm{g}$ human heart total RNA (Ambion), 5 $\mu \mathrm{g}$ human fetal brain total RNA (BD Biosciences Clontech, Palo Alto, CA, USA), $5 \mu \mathrm{g}$ human thyroid total RNA, and $5 \mu \mathrm{g}$ total RNA from human carotid tissue. Total RNA from thyroid and carotid tissue were purified with NucleoSpin ${ }^{\circledR}$ RNA II extraction kit (Macherey-Nagel, Düren, Germany). For alfalfa reference RNA, $14 \mu \mathrm{g}$ total RNA from the following tissues were pooled: flower, leaf, root, seed, and germ. This RNA was mixed with $10 \mu \mathrm{g}$ total RNA prepared from protoplasts. For RNA purification the FastRNA ${ }^{\circledR}$ kit (BIO 101, Vista, CA, USA) was used. The quality of the extracted RNA was assessed by gel electrophoresis, as well as by $\mathrm{A}_{260 / 280}$ ratios.

\section{Reference cDNA Synthesis}

Thirty-three microliters pooled total RNA $(80 \mu \mathrm{g})$ from different organisms were reverse transcribed in a total volume of $60 \mu \mathrm{L}$. For the synthesis of antisense reference RNA, total RNA was mixed with $3 \mu \mathrm{L}(100 \mathrm{pmol} / \mu \mathrm{L})$ $\mathrm{T}_{7 \mathrm{~T}}{ }_{25} \mathrm{~V}$ and $3 \mu \mathrm{L}(100 \mathrm{pmol} / \mu \mathrm{L}) \mathrm{FOR}$ primers, and $3 \mu \mathrm{L}(20 \mathrm{U} / \mu \mathrm{L}) \mathrm{RNasin}^{\circledR}$ (MBI Fermentas, Vilnius, Lithuania), heated to $75^{\circ} \mathrm{C}$ for $5 \mathrm{~min}$ and cooled on ice. To this mixture, $12 \mu \mathrm{L} 5 \times$ firststrand buffer (MBI Fermentas), $3 \mu \mathrm{L}$ $10 \mathrm{mM}$ dNTP mixture, and $3 \mu \mathrm{L}, 200$ $\mathrm{U} / \mu \mathrm{L}$ RNase $\mathrm{H}^{-}$point mutant Moloney murine leukemia virus (MMLV) reverse transcriptase (MBI Fermentas) were added and incubated at $42^{\circ} \mathrm{C}$ for $2 \mathrm{~h}$. For the production of sense refer- ence RNA, the same protocol is used as for cDNA synthesis, but $\mathrm{REVT}_{25} \mathrm{~V}$ and T7FOR primers were used instead of $\mathrm{T}_{7} \mathrm{~T}_{25} \mathrm{~V}$ and FOR primers. After cDNA synthesis, $240 \mu \mathrm{L}$ TE $(10 \mathrm{mM}$ Tris- $\mathrm{HCl}, \mathrm{pH} 7.5,0.2 \mathrm{mM}$ EDTA) were added.

\section{Exponential Amplification of Reference cDNA}

From the first-strand cDNA synthesis reaction mixture, $0.5 \mu \mathrm{L}$ were amplified in a total volume of $100 \mu \mathrm{L}$ PCR with $\mathrm{REVT}_{25} \mathrm{~V}$ and T7FOR, or REVT and T7FOR primers in case of sense reference RNA production, or $\mathrm{T}^{2} \mathrm{~T}_{25} \mathrm{~V}$ and FOR, or T7T and FOR primer pairs in case of antisense amplified RNA production. The reaction mixture contained $50 \mathrm{nM}$ final concentration of each primers, $1 \times$ PCR buffer (Amersham Biosciences, Piscataway, NJ, 
USA), 4 U Taq DNA polymerase (Amersham Biosciences), and $200 \mu \mathrm{M}$ dNTP. Amplification was done under the following conditions: initial denaturation at $95^{\circ} \mathrm{C}$ for $1 \mathrm{~min}, 22$ cycles of denaturation at $95^{\circ} \mathrm{C}$ for $35 \mathrm{~s}$, annealing at $58^{\circ} \mathrm{C}$ for $40 \mathrm{~s}$, and extension at $68^{\circ} \mathrm{C}$ for $4 \mathrm{~min}$. PCR products were purified with a PCR purification kit (Qiagen, Hilden, Germany), according to the manufacturer's instructions, but eluted twice with $40 \mu \mathrm{L} 1 / 5$ Elution buffer. The concentration of the eluted dsDNA was determined by UV absorbance measurement at $260 \mathrm{~nm}$. The usual yield was approximately $2 \mu \mathrm{g}$ DNA from $100 \mu \mathrm{L}$ PCR. Forty reactions were performed from each cDNA synthesis reaction mixture from the different pooled samples. The purified PCR products were pooled, vacuum-concentrated using an Automatic SpeedVac AS160 (Savant Instrument, Farmingdale, NY, USA) and dissolved in
DEPC-treated water to a final concentration of $500 \mathrm{ng} / \mu \mathrm{L}$.

\section{Production of Reference RNA Using In Vitro Transcription}

PCR-amplified cDNA template (20 $\mu \mathrm{g})$ was transcribed in a total volume of $200 \mu \mathrm{L}$ using Ribomax Large Scale RNA Production System (Promega), according to the manufacturer's instructions. The RNA was diluted with $0.3 \mathrm{~mL}$ DEPC-treated water, purified using 15 columns from the RNeasy ${ }^{\circledR}$ purification kit (Qiagen), and measured spectroscopically. The usual yield was 1.5-2 mg amplified RNA, which corresponds to $150-200 \times$ amplification of the PCR-amplified DNA. For longterm storage, RNA was aliquoted (aliqouts contained $30 \mu \mathrm{g}$ amplified RNA) in the presence of RNasin (final concentration of $0.1 \mathrm{U} / \mu \mathrm{L}$ ), dried using speed vacuum, and stored at $-80^{\circ} \mathrm{C}$.

\section{Probe Preparation and Labeling}

Amplified reference RNA $(2.5 \mu \mathrm{g})$ was labeled with $\mathrm{Cy} 3$ during reverse transcription using $0.4 \mu \mathrm{M}$ random nonamer as primer, $0.1 \mathrm{mM} \mathrm{d}(\mathrm{G} / \mathrm{T} /$ A)TPs, $0.05 \mathrm{mM}$ dCTP (Amersham Biosciences), 20 U RNasin (MBI Fermentas), $1 \times$ first-strand buffer, $200 \mathrm{U}$ RNAse $\mathrm{H}^{-}$point mutant MMLV reverse transcriptase, and $0.05 \mathrm{mM} \mathrm{Cy} 3-\mathrm{dCTP}$ (Amersham Biosciences) in $20 \mu \mathrm{L}$ total volume. The RNA, primer, and RNasin were denatured at $75^{\circ} \mathrm{C}$ for $5 \mathrm{~min}$ and cooled on ice before adding the remaining reaction components. After $2 \mathrm{~h}$ incubation at $37^{\circ} \mathrm{C}$, the heteroduplexes were denatured and the mRNA was hydrolyzed with $\mathrm{NaOH}(250 \mathrm{mM}$ final concentration) for $15 \mathrm{~min}$ at $37^{\circ} \mathrm{C}$ and neutralized with $10 \mu \mathrm{L} 2 \mathrm{M}$ MOPS (pH 6.0). The labeled cDNA was purified with a PCR purification kit, according to the manufacturer's instructions, but 
Table 1. Sequences of Oligodeoxynucleotides Used

\begin{tabular}{|ll|}
\hline Name & \multicolumn{1}{c|}{ Sequence $\left(\mathbf{5}^{\prime} \rightarrow \mathbf{3}^{\prime}\right)$} \\
\hline $\mathrm{T}^{\prime} \mathrm{T}_{25} \mathrm{~V}$ & GGCCAGTGAATTGTAATACGACTCACTATAGGGAGGCGG $\left(\mathrm{T}_{25} \mathrm{~V}\right.$ \\
$\mathrm{REVT}_{25} \mathrm{~V}$ & TGTCTGCAGTGGTAACAACGCAGAGTACG $\left(\mathrm{T}_{25} \mathrm{~V}\right.$ \\
$\mathrm{T} 7 \mathrm{~T}$ & GGCCAGTGAATTGTAATACGACTCACTATAGGGAGGCGGTTT \\
REVT & TGTCTGCAGTGGTAACACGCAGAGTACGTTT \\
T7FOR & GGCCAGTGAATTGTAATACGACTCACTATAGGGAGGCGGG \\
FOR & TGTCTGCAGTGGTAACAACGCAGAGTACGCGGG \\
\hline
\end{tabular}

eluted twice with $40 \mu \mathrm{L}$ 1/2 Elution buffer. The probes were concentrated $\mu \mathrm{L}$ hybridization buffer $(50 \%$ formamide, $5 \times$ SSC, $0.1 \%$ SDS, 100 $\mu \mathrm{g} / \mathrm{mL}$ salmon sperm DNA).

\section{Array Hybridization and Post- hybridization Processes}

In case of human heart expression monitoring, prehybridization was done by adding $1 \mu \mathrm{L} 4 \mathrm{mg} / \mathrm{mL}$ poly(T), $2 \mu \mathrm{L}$ $2 \mathrm{mg} / \mathrm{mL}$ human Cot DNA (Invitrogen), and $2 \mu \mathrm{L} 1 \mathrm{mg} / \mathrm{mL} \lambda$ DNA (MBI Fermentas) to the hybridization mixture. by speed vacuum and dissolved in 20

For hybridization of labeled reference cDNA, $2 \mu \mathrm{L} 1 \mathrm{mg} / \mathrm{mL} \lambda$ DNA and $2 \mu \mathrm{L}$ $1 \mathrm{mg} / \mathrm{mL}$ salmon sperm DNA were added. The probe mixture was incubated at $42^{\circ} \mathrm{C}$ for $30 \mathrm{~min}$ after denaturation by heating for $5 \mathrm{~min}$ at $80^{\circ} \mathrm{C}$. Twenty microliters of the mixture were placed on the blocked array under a $24 \times 32$ mm coverslip (Menzel-Glaser, Germany). To the edges of the coverslip DPX Mountant (Fluka) was poured to prevent evaporation. Slides were incubated at $42^{\circ} \mathrm{C}$ for $18 \mathrm{~h}$ in a humid hybridization chamber. After hybridization, the mountant was removed and the arrays were washed as described (6). Scanning

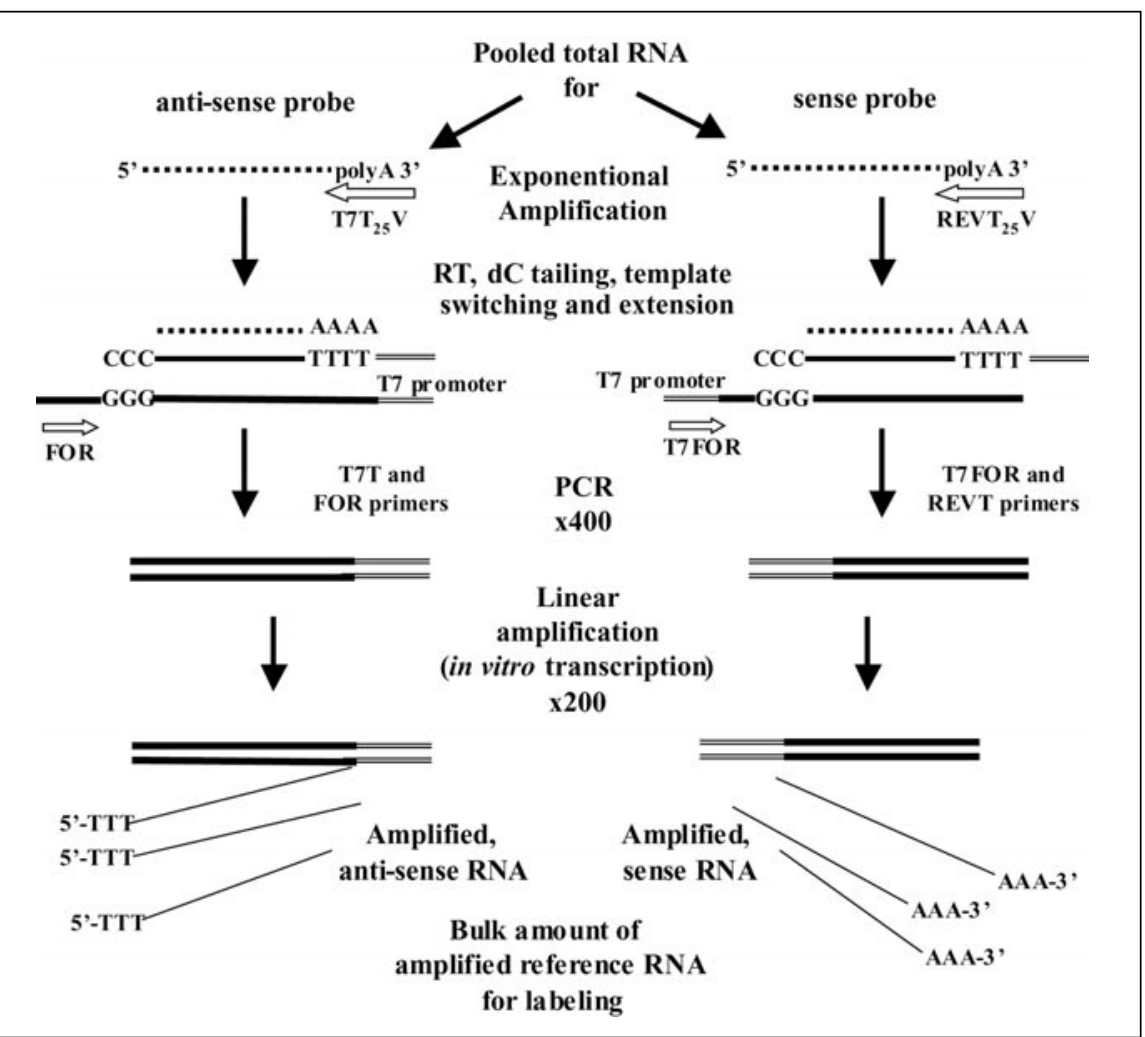

Figure 1. Summary of the method used in this study. A bulk amount of sense and antisense reference RNA can be obtained with combinations of exponential (PCR) and linear (in vitro transcription) amplification methods. and data analysis were performed as described previously (4). Briefly, following image analysis, genes were labeled ON or OFF according to a predetermined intensity threshold. The threshold was set at 1.5 times of the local background intensity. This cut-off level was determined from the "CH1GTB2" values (obtained from the ScanAlyze2 software, version 2.32; www.microarrays.org/software.html), which corresponds to a fraction of pixels in the spot greater than 1.5 times the background. Only if the mean spot intensity was greater than this threshold was a spot considered significantly above background. Each clone was spotted twice; thus, an average intensity could be calculated for the replicate spots.

\section{RESULTS AND DISCUSSION}

The application of common reference RNA provides an internal control and thus normalizes differences in hybridization parameters and array variations. The reference RNA should represent a mixture of different gene products with the highest possible complexity. The reference RNA, produced by our method corresponds to $\operatorname{poly}(\mathrm{A})^{+}$sequences and can be prepared in bulk amounts sufficient for thousands of experiments at low cost.

Mixtures of total RNA isolated from different tissues deriving from different organisms, including human, rat, and alfalfa were prepared. In case of a human total RNA pool, commercially available Universal Human Reference RNA was mixed with additional total RNA isolated from different tissues to increase the complexity of the mixture. In case of the other samples, purified or commercially available total RNA were mixed. We used these mixtures as starting material for amplification to obtain labeled sense or antisense reference cDNA.

To obtain a bulk amount of reference RNA starting from $80 \mu \mathrm{g}$ pooled total RNA, a double amplification technique was applied. The summary of the method can be seen in Figure 1. At first, total RNA pools from different organisms were reverse-transcribed using a modified SMART ${ }^{\mathrm{TM}}$ cDNA synthesis technique (BD Biosciences Clontech). For the production of antisense probe, $\mathrm{T}_{7 \mathrm{~T}}{ }_{25} \mathrm{~V}$ and FOR primers were added 


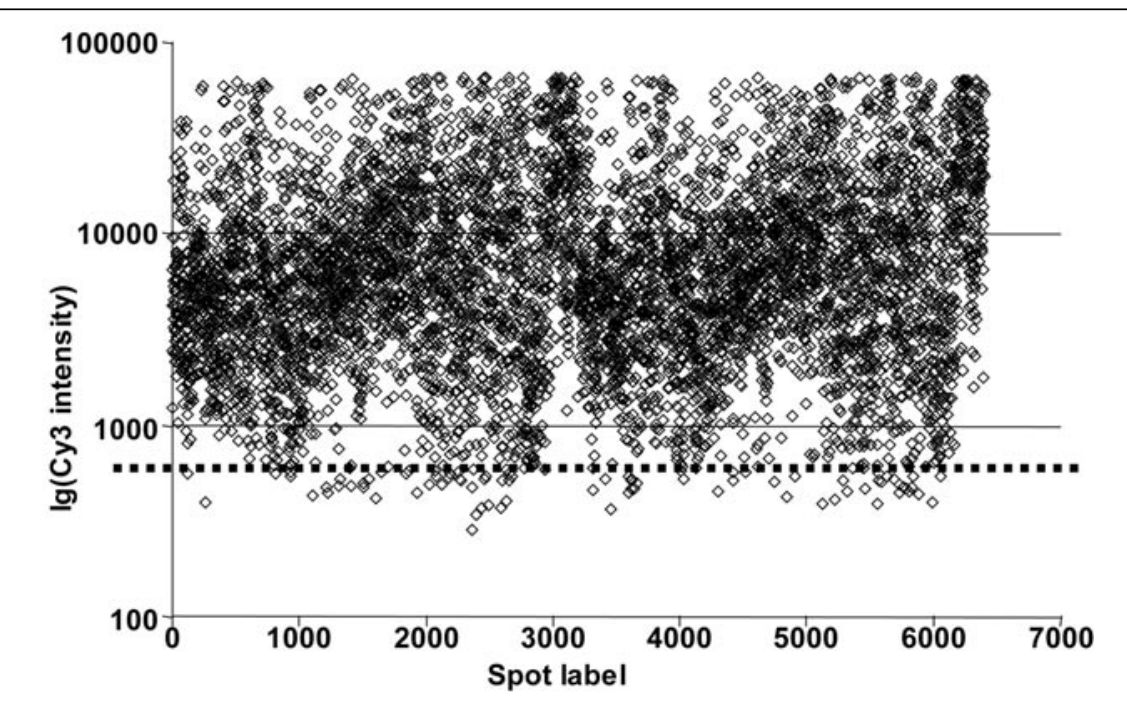

Figure 2. Signal distribution among 6400 spots (for number of individual samples, see spot label on $x$-axis) on the rat microarray demonstrates that $92 \%$ of the spots have significantly higher intensity than background (the ratio of the mean spot and local background intensities was higher than 1.5).

to the reverse transcription mixture, while in case of sense probe preparation, $\mathrm{REVT}_{25} \mathrm{~V}$ and $\mathrm{T} 7 \mathrm{FOR}$ primers were used. T7 denotes for the T7 RNA polymerase promoter sequence at the $5^{\prime}$-end of the primers. All the oligonucleotides used in this study were HPLC-purified (Table 1). After PCR amplification of the cDNA pool, a dsDNA mixture was generated that had $\mathrm{T} 7$ promoter sequence at $5^{\prime}$ - or $3^{\prime}$-end relative to the orientation of the original RNA. With this exponential amplification, we could achieve approximately a 400-fold improvement in the yield of the starting nucleic acid. After PCR, a second amplification, an in vitro transcription was carried out. From a DNA template with a $\mathrm{T} 7$ promoter at the $3^{\prime}$ end [relative position to the poly(A) tail of the mRNA], antisense RNA was produced that could be labeled by the incorporation of Cy5- or Cy3-labeled dUTP or dCTP using random oligonucleotides as primers in a reverse transcription reaction. If the $\mathrm{T} 7$ promoter were at the other side, then sense RNA was produced that could be primed both with random and oligo(dT) oligonucleotides. From alfalfa and rat, antisense RNA was produced. From human, both sense and antisense RNA were generated. In all cases, the average yield of the double amplification was $1.5-2$ mg RNA, starting from $1 / 12$ of the PCR-amplified templates.
To test the quality of the reference RNA, we synthesized Cy3 fluorescently labeled cDNA samples from all the organisms and hybridized them to the species-specific microarrays. Alfalfa, rat, human antisense RNA, and human sense RNA were converted into labeled samples. Human and rat reference samples were hybridized onto DNA microarrays containing 6400 spots (3200 different genes in duplicate); the alfalfa samples were tested on an array containing 1600 genes. Representative images of alfalfa and human arrays were prepared, and the percentage of spots with signals that were significantly above background were $90 \%, 92 \%$, and $91 \%$ for alfalfa, rat, and human, respectively (data not shown). Figure 2 shows the signal distribution among 6400 spots on the rat microarray. All the arrays showed high signals in almost all the spots, which confirmed the high complexity and good applicability of the obtained reference probes. Thus, amplified reference RNA could serve as reliable standard, could help to create normalized expression databases, and delivers the possibility for interlaboratory comparisons.

\section{ACKNOWLEDGMENTS}

This work was supported by Hungarian National Science and Development
Foundation grant no. NKFP 1/040, Biotechnológia 2000 grant no. OMFB, BIO-0005/2000, and Hungarian National Scientific Research Foundation (OTKA) grant no. F034637. The authors thank S. Bottka and Z. Kupihár for the preparation and purification of the oligonucleotides, and A. Ábrahám and R.T. Dudásné for their technical support.

\section{REFERENCES}

1.Alizadeh, A.A., M.B. Eisen, R.E. Davis, C. Ma, I.S. Lossos, A. Rosenwald, J.C. Boldrick, H. Sabet, et al. 2000. Distinct types of diffuse large B-cell lymphoma identified by gene expression profiling. Nature 403:503-511.

2.Eisen, M.B. and P.O. Brown. 1999. DNA arrays for analysis of gene expression. Methods Enzymol. 303:179.

3.Hughes, T.R., M. Mao, A.R. Jones, J. Burchard, M.J. Marton, K.W. Shannon, S.M. Lefkowitz, et al. 2001. Expression profiling using microarrays fabricated by an ink-jet oligonucleotide synthesizer. Nat. Biotechnol. 19:342-347.

4.Kitajka, K., L.G. Puskás, A. Zvara, L. Hackler, Jr., G. Barceló-Coblijn, Y.K. Yeo, and T. Farkas. 2002. The role of n-3 polyunsaturated fatty acids in brain. Modulation of rat brain gene expression by dietary $\mathrm{n}-3$ fatty acids. Proc. Natl. Acad. Sci. USA 99:2619-2624.

5.Lee, M-L.T., F.C. Kuo, G.A. Whitmore, and J. Sklar. 2000. Importance of replication in microarray gene expression studies: statistical methods and evidence from repetitive cDNA hybridizations. Proc. Natl. Acad. Sci. USA 97:9834-9839.

6.Puskás, L.G., A. Zvara, L. Hackler, Jr., and P. Van Hummelen. 2002. RNA amplification results in reproducible microarray data with slight ratio biases. BioTechniques. 32:13301340.

7.Scherf, U., D.T. Ross, M. Waltham, L.H. Smith, J.K. Lee, L. Tanabe, K.W. Kohn, W.C. Reinhold, et al. 2000. A gene expression database for the molecular pharmacology of cancer. Nat. Genet. 24:236-244.

Received 28 February 2002; accepted 2 May 2002.

Address correspondence to:

Dr. László G. Puskás

DNA-chip Laboratory

Biological Research Center

Hungarian Academy of Sciences

Szeged, P.O. Box 521, H-6701, Hungary

e-mail:pusi@nucleus.szbk.u-szeged.hu 